\title{
Skin tear treatment and prevention by nurses: an integrative literature review
}

\author{
Cuidado e prevenção das skin tears por \\ enfermeiros: revisão integrativa de literatura \\ Cuidado y prevención de skin tears por enfermeros: \\ revisión integradora de la literatura
}

\section{Érick Igor dos Santos ${ }^{\mathrm{a}}$}

\begin{abstract}
The objective of the present study was to identify scientific evidence in the literature regarding management and prevention of skin tears by nurses over the last ten years. This is an integrative review of articles found in the LILACS, SciELO, BDENF, MEDLINE, Scopus, ScienceDirect and PubMed databases, identified with the Portuguese, English and Spanish descriptors for "skin," "friction," or with the keyword "skin tears". After inclusion and exclusion criteria were applied, fifteen texts were selected. Scientific evidence demonstrated that the best management results are obtained by covering the tear with the skin flap itself, using octylcyanoacrylate or silicone-based products. Prevention consists of promoting a safe environment, through multidisciplinary work and health education. We conclude that it is the nursing staff's responsibility to avoid infection, trauma of any intensity, pain and bleeding.
\end{abstract}

Descriptors: Wounds and injuries. Friction. Skin. Nursing care. Nurses.

\section{RESUMO}

Este estudo teve por objetivo caracterizar as evidências científicas dos últimos dez anos sobre a enfermagem no cuidado e prevenção das lesões do tipo skin tears. Trata-se de uma revisão integrativa de literatura de artigos completos presentes nas bases LILACS, SciELO, BDENF, MEDLINE, Scopus, ScienceDirect e PUBMED acessáveis com os descritores "pele" and "fricção" and "enfermagem" em português, inglês ou espanhol, ou com a palavra-chave "skin tears". Foram selecionados quinze artigos após a aplicação dos critérios de inclusão e de exclusão. A cobertura com o próprio retalho de pele, com produtos à base de octilcianoacrilato ou de silicone são as evidências científicas com melhores resultados para serem aplicadas por enfermeiros. A prevenção consiste na promoção de ambiente seguro, com trabalho multidisciplinar e educação em saúde. Conclui-se caber à enfermagem evitar infecção, traumas de qualquer intensidade, dor e hemorragia.

Descritores: Ferimentos e lesões. Fricção. Pele. Cuidados de Enfermagem. Enfermeiras.

\section{RESUMEN}

El objetivo de ese estudi fue caracterizar las evidencias científicas de los últimos diez años sobre la enfermería en el cuidado y la prevención de skin tears. erase trata de una revisión integradora de los artículos presentes en las bases LILACS, SciELO, BDENF, MEDLINE, Scopus, ScienceDirect y PubMed, accesible con los descriptores "piel"y "fricción"y "enfermería" en portugués, inglés o español, o con la palabra clave "fisuras en la piel". Se seleccionaron 15 artículos después de la aplicación de los criterios de inclusión y exclusión. La cobertura con el propio retazo de piel, con productos a base de octilcianoacrilato o silicona tenían la evidencia cientíica con los mejores resultados para la práctica de los enfermeros. La prevención consiste en la promoción de un ambiente seguro, con un trabajo multidisciplinario y educación sanitaria. Se concluyó que le corresponde a los enfermeros evitar la infección, trauma de cualquier intensidad, dolor y hemorragia.

Descriptores: Heridas y lesiones. Fricción. Piel. Atención de Enfermería. Enfermeros. http://dx.doi.org/10.1590/1983-

1447.2014.02.45178 


\section{IINTRODUCTION}

Skin tears are lesions caused by trauma, be it through friction, blunt-force or shearing. The tension caused by retraction, friction or hitting one's skin against the surface of a hospital bed or on surrounding objects can cause partial or full thickness wounds. The regions of the body most affected by skin tears are the back of the hand, arms, elbows and the legs of elderly or very young individuals, such as neonates. Serous exudate production, especially within the first 24 hours, makes skin tears mostly humid. Although Brazilian data regarding these types of lesions remain limited, its prevalence is greater than that of pressure ulcers and there is a tendency for the number of cases to increase in the years to come. ${ }^{(1-10)}$

Even though the period between 1993 and 2007 was productive in terms of concept definition, formal investigation, and the creation of clinical protocols for classifying skin tears, an international survey conducted in 2011 led to the creation of a formal document expressing a consensus among specialists from different countries. This document presents a more current definition of skin tears, which is used as a theoretical basis for the present research. ${ }^{\left({ }^{8}\right)}$

These types of lesions are predominantly the consequence of frailties of the elderly person's body, such as thinning of the skin and the reduction of its humidity, elasticity and resistance, all of which intensify after the age of 75. ${ }^{(2,8)}$

For some authors, skin tears can be considered indicators for quality of care, since in most cases they are related to how objects are arranged in the individual's environment. ${ }^{(5)}$

Based on these issues, the following research question was formulated: What scientific evidence regarding skin tear management and prevention by nurses has been produced over the last ten years? National and international scientific evidence on the topic of skin tear management and prevention conducted by nurses was the object of this study. The aim was to characterize national and international scientific evidence in the literature regarding management and prevention of skin tears by nurses over the last ten years.

This theme is relevant because of the potential increased incidence of these types of lesions with the increase in the aging population, ${ }^{(4,6)}$ the threat presented by skin tears to the quality of life of the elderly, and the high costs of non-evidence based interventions and the time spent by the nursing staff to care for patients with these types of lesion. ${ }^{(5)}$ It is also relevant due to the deficit of research, ${ }^{(2,8)}$ especially in Brazil, which could provide nursing professionals with clear guidelines for skin tear management and prevention. ${ }^{(3)}$

\section{METHOD}

This is an integrative literature review, ${ }^{(11)}$ a research method which includes searching for, critically analyzing and synthesizing the evidence available on skin tears and their management. The six steps inherent to this method were followed, namely, research question formulation, literature search, categorizing studies, evaluating the studies included in the review, interpretation of results and review presentation.

The following research question was formulated: What scientific evidence regarding skin tear management and prevention by nurses has been produced over the last ten years?

\section{Inclusion criteria}

The inclusion criteria adopted to guide the search and selection of publications were:

a) Articles published in peer-reviewed national and international scientific journals which report research on skin tears and their management and prevention by nursing professionals;

b) Articles published in Portuguese, English or Spanish;

c) Articles published between 2003 and 2013, i.e., over the last ten years, taking into consideration the need for current information on the theme;

d) Articles indexed in at least one of the following databases: Latin American and Caribbean Health Science Literature (LILACS), the Nursing Database (BDENF), Medical Literature Analysis and Retrieval System Online (MEDLINE), Elsevier SciVerse Scopus, Elsevier SciVerse ScienceDirect Journals, National Library of Medicine (PUBMED) or in the Scientific Electronic Library Online (SciELO), and when an article was not directly available through the respective database, we consulted the Coordination for the Improvement of Higher Level Personnel Portal (CAPES) in order to locate and access it;

e) Articles located using the keyword "skin tears" or a combination of the following descriptors registered in the Health Sciences Descriptor Portal (DeCS): "skin" and "friction" and "nursing," "pele" and "fricção" and "enfermagem" or "piel" and "fricción" and "enfermería." The term "skin tears" was used separately as a keyword, for it is not currently registered in the DeCS. The descriptors "skin" and "friction" were cross-referenced with "nursing" because a large portion of the research otherwise encountered was not related to the objective of the present study, for example the management of skin tears in animals. We consulted the databases a total of four times. 
f) In order to include an article in our study, we read each title and abstract carefully so as to verify its agreement with the investigation's guiding question. When there was any doubt about whether or not a study should be included, it was read in its entirety in order to reduce the risk of losing relevant publications. Below, we include a flowchart displaying the steps involved in article selection (Figure 1).

\section{Exclusion criteria:}

a) Publications that were not available as full text;

b) Publications that were available as full text, but whose link presented an error message upon attempted access;

\section{Data collection instrument}

Data were collected between July and December of 2013, using a data collection instrument created with the Microsoft Office Excel 2010 software. The following variables were used: title of article, authors, periodical, year of publication, country of origin, study type/approach, database in which it is indexed, descriptors/keywords used, level of evidence ${ }^{(12)}$, and established recommendations for nursing care management and prevention strategies.

\section{RESULTS}

We identified 13,625 texts, which upon being read in their entirety and submitted to the pre-established inclusion and exclusion criteria, were reduced to 15 . Of the 13,625 identified studies, 3,822 were not available free of charge in the databases and were not found in the CAPES Periodical Portal; 4,788 were not pertinent to the theme; 3,697 were published prior to 2003; and 1,303 were available only in languages other than Portuguese, English or Spanish. All of these characteristics limited the study. We found the greatest number of publications in the Elsevier SciVerse Science Direct Journals and Elsevier SciVerse Scopus. On the other hand, regarding the publications that complied with our methodological criteria, the majority was found in MEDLINE and Elsevier SciVerse ScienceDirect Journals. We observed that combining the descriptors was not as effective for tracking down publications as using the single term "skin tears" (Chart 1). This could be a consequence of the popularization of the term in the 1990s for referring to these types of lesions. ${ }^{(8)}$

The low number of articles found in the LILACS, SciELO and BDENF databases highlight the scarcity of scientific publications (or at least of their availability in Latin America's largest databases) in nursing regarding the theme.

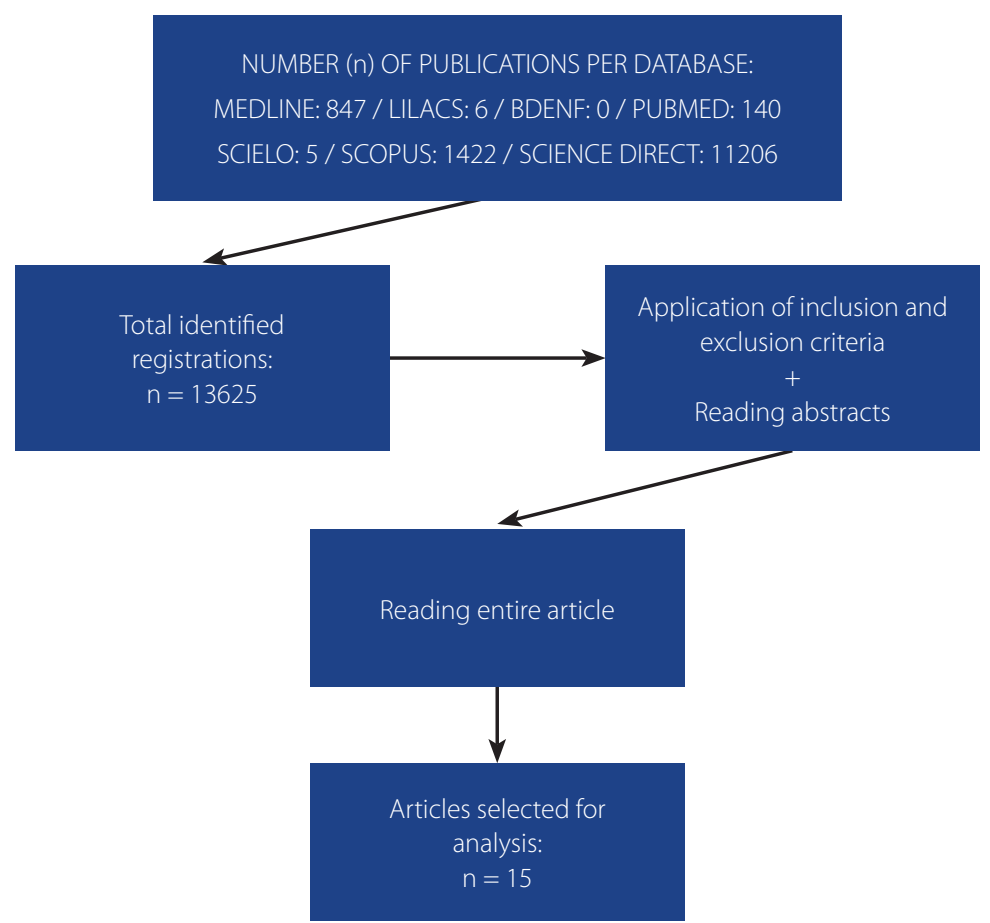

Figure 1. Flowchart of the methodological steps carried out for article selection. Rio de Janeiro, RJ, 2014.

Source: research data. 


\begin{tabular}{|c|c|c|c|c|c|}
\hline \multirow{3}{*}{ Database } & \multicolumn{2}{|c|}{ Descriptors } & \multicolumn{2}{|c|}{ Keywords } & \multirow{3}{*}{$\begin{array}{c}\text { Total per } \\
\text { base }\end{array}$} \\
\hline & \multicolumn{2}{|c|}{$\begin{array}{l}\text { "skin" and "friction" and "nursing" } \\
\text { "pele" and "friç̧ão" and "enfermagem" } \\
\text { "piel" and "fricción" and "enfermeria" }\end{array}$} & \multicolumn{2}{|c|}{ "skin tears" } & \\
\hline & $\mathbf{F}$ & $\mathbf{S}$ & $\mathbf{F}$ & $\mathbf{S}$ & \\
\hline LILACS & 0 & 0 & 5 & 1 & 6 \\
\hline ScIELO & 0 & 0 & 5 & 0 & 5 \\
\hline BDENF & 0 & 0 & 0 & 0 & 0 \\
\hline MEDLINE & 77 & 0 & 765 & 5 & 847 \\
\hline Elsevier SciVerse Scopus & 64 & 1 & 1353 & 3 & 1421 \\
\hline $\begin{array}{l}\text { Elsevier SciVerse ScienceDi- } \\
\text { rect Journals }\end{array}$ & 689 & 0 & 10512 & 5 & 11206 \\
\hline PUBMED & 64 & 0 & 76 & 0 & 140 \\
\hline \multirow[t]{3}{*}{ TOTAL PER TERM } & 894 & 1 & 12711 & 14 & \\
\hline & \multicolumn{4}{|c|}{ Publications found } & 13625 \\
\hline & \multicolumn{4}{|c|}{ Publications selected } & 15 \\
\hline
\end{tabular}

Chart 1. Number (n) of articles found (F) and selected (S) after integrative review, per database. Rio de Janeiro, RJ, 2014.

Source: research data

Only one Brazilian article was found and selected. This scarcity has been detected by other studies in Brazil and abroad. $(2,3,8)$

Chart 2 displays the article distribution by analyzed variable, with the exception of established recommendations for nursing care for skin tear management and prevention, which will be discussed separately. With exception to Brazil, which presented one article, the other countries that reported studies on skin tears were the United States (USA) with seven articles, Australia with two, the United Kingdom with two, Canada and New Zealand with one each, and another article written by authors from more than one country.

Regarding the year of publication, a continual increase was noticed in the number of publications and a latent increase in 2013 (Chart 2). The greatest number of studies on skin tears were published in 2011, with four articles, followed by 2009, with three, and 2012 and 2013 tied with two articles each. Among the periodicals which most stood out in the field, we found The British Journal of Community Nursing, with two published articles in the same volume. All other articles were published in separate volumes.

The scientific evidence was analyzed by applying the hierarchical system for classifying the quality of evidence (12) to the methodological data of the studies presented in Chart 2. As observed, according to the stratification by level of evidence, there are four level- 6 articles, two level-5 articles, four level-4 articles, two level-3, and three level-2. If on the one hand there is a great variety among the publications regarding their level of evidence, on the other we observed that there are few high evidence level studies available. Articles on skin tear with significant levels of evidence are important in order to increase the use of scientific information and improve the scientific basis for health and nursing care practices directed at patients with these kinds of lesions.

Discussion of the results was divided into the two major axes that emerged after categorizing the studies, as suggested by the methodological framework of Integrative Literature Reviews. ${ }^{(11)}$

\section{DISCUSSION}

\section{On the recommendations for nursing care for treating patients with skin tears}

A deficit of solid scientific framework was found for practices linked to skin tears. ${ }^{(5)}$ The ideal dressing must be simple, quick, painless, comfortable, easily removable, serve as a protective barrier against bacterial invasion, and sufficiently strong and resistant while not interfering with daily activities. ${ }^{(10)}$

The product used for confecting a skin tear dressing needs to be chosen according to the classification of the 


\begin{tabular}{|c|c|c|c|c|c|}
\hline $\begin{array}{l}\text { Author/ } \\
\text { Country }\end{array}$ & $\begin{array}{c}\text { Periodical/ } \\
\text { Year }\end{array}$ & $\begin{array}{l}\text { Study type/ } \\
\text { approach }\end{array}$ & Database & $\begin{array}{l}\text { Descriptor/ } \\
\text { Keyword }\end{array}$ & $\begin{array}{l}\text { Level of } \\
\text { Evidence }\end{array}$ \\
\hline $\begin{array}{l}\text { Amaral AFS, Pulido } \\
\text { KCS, Santos VLCG / } \\
\text { Brazil }\end{array}$ & $\begin{array}{l}\text { Rev Esc Enferm } \\
\text { USP / } 2012\end{array}$ & $\begin{array}{l}\text { Epidemiologic and } \\
\text { exploratory }\end{array}$ & LILACS & "skin tears" & 3 \\
\hline $\begin{array}{l}\text { Kazandjiean DG, } \\
\text { Okulicz JF/USA }\end{array}$ & Am J Med / 2006 & Case study & $\begin{array}{l}\text { Elsevier SciVerse Sci- } \\
\text { enceDirect Journals }\end{array}$ & "skin tears" & 5 \\
\hline $\begin{array}{l}\text { Milne CT, Corbett } \\
\text { LQ/USA }\end{array}$ & Geriatr Nurs / 2005 & Prospective & $\begin{array}{l}\text { Elsevier SciVerse Sci- } \\
\text { enceDirect Journals }\end{array}$ & "skin tears" & 2 \\
\hline Cuzzell J / USA & $\begin{array}{l}\text { Dermatol Nurs / } \\
2003\end{array}$ & Opinion & $\begin{array}{l}\text { Elsevier SciVerse Sci- } \\
\text { enceDirect Journals }\end{array}$ & "skin tears" & 6 \\
\hline $\begin{array}{l}\text { Benbow M / United } \\
\text { Kingdom }\end{array}$ & $\begin{array}{l}\text { Br J Community } \\
\text { Nurs / } 2009\end{array}$ & Opinion & $\begin{array}{l}\text { Elsevier SciVerse Sci- } \\
\text { enceDirect Journals }\end{array}$ & "skin tears" & 6 \\
\hline $\begin{array}{l}\text { Ousey K/ United } \\
\text { Kingdom }\end{array}$ & $\begin{array}{l}\text { Br J Community } \\
\text { Nurs / } 2009\end{array}$ & Opinion & $\begin{array}{l}\text { Elsevier SciVerse Sci- } \\
\text { enceDirect Journals }\end{array}$ & "skin tears" & 6 \\
\hline $\begin{array}{l}\text { Kotowski SE, Davis } \\
\text { KG, Wiggermann N, } \\
\text { Williamson R / USA }\end{array}$ & $\begin{array}{l}\text { Hum Factors / } \\
2013\end{array}$ & $\begin{array}{l}\text { Clinical-laboratorial } \\
\text { quantitative study }\end{array}$ & $\begin{array}{l}\text { Elsevier SciVerse } \\
\text { Scopus }\end{array}$ & $\begin{array}{l}\text { "skin" and } \\
\text { "friction" and } \\
\text { "nursing" }\end{array}$ & 2 \\
\hline $\begin{array}{l}\text { Kennedy P, Kerse N / } \\
\text { New Zealand }\end{array}$ & $\begin{array}{l}\text { J Am Geriatr Soc / } \\
2011\end{array}$ & Epidemiologic & MEDLINE & "skin tears" & 3 \\
\hline $\begin{array}{l}\text { Lopez V, Dunk AM, } \\
\text { Parke J, Larkin D, } \\
\text { Trudinger M, Stuart } \\
\text { M / Australia }\end{array}$ & $\begin{array}{l}\text { Int J Evid Based } \\
\text { Healthc / } 2011\end{array}$ & Survey & MEDLINE & "skin tears" & 4 \\
\hline $\begin{array}{l}\text { Xu XBS, Lau K, Taira } \\
\text { BR, Singer AJ / USA }\end{array}$ & $\begin{array}{l}\text { Am J Emerg Med } \\
\text { / } 2009\end{array}$ & Review & MEDLINE & "skin tears" & 4 \\
\hline $\begin{array}{l}\text { Holmes RF, Davidson } \\
\text { MW, Thompson BJ, } \\
\text { Kelechi TJ / USA }\end{array}$ & $\begin{array}{l}\text { Home Healthc } \\
\text { Nurse / } 2013\end{array}$ & Review & MEDLINE & "skin tears" & 4 \\
\hline $\begin{array}{l}\text { LeBlanc K, Baranoski } \\
\text { S/ Several countries }\end{array}$ & $\begin{array}{l}\text { Adv Skin Wound } \\
\text { Care / } 2011 \\
\end{array}$ & $\begin{array}{l}\text { Specialist Consen- } \\
\text { sus Panel }\end{array}$ & MEDLINE & "skin tears" & 6 \\
\hline $\begin{array}{l}\text { Bajwa AA, Arasi L, } \\
\text { Canabal JM, Kramer } \\
\text { DJ / USA }\end{array}$ & $\begin{array}{l}\text { J Intensive Care } \\
\text { Med / } 2010\end{array}$ & $\begin{array}{l}\text { Retrospective clini- } \\
\text { cal study }\end{array}$ & $\begin{array}{l}\text { Elsevier SciVerse } \\
\text { Scopus }\end{array}$ & "skin tears" & 2 \\
\hline $\begin{array}{l}\text { Foster RS, Chan J / } \\
\text { Australia }\end{array}$ & $\begin{array}{l}\text { Aust J Dermatol / } \\
2011 \\
\end{array}$ & Case study & $\begin{array}{l}\text { Elsevier SciVerse } \\
\text { Scopus }\end{array}$ & "skin tears" & 5 \\
\hline $\begin{array}{l}\text { Maida V, Ennis M, } \\
\text { Corban J / Canada }\end{array}$ & Int Wound J / 2012 & Prospective study & $\begin{array}{l}\text { Elsevier SciVerse } \\
\text { Scopus }\end{array}$ & "skin tears" & 4 \\
\hline
\end{tabular}

Chart 2. Articles found after integrative literature review by analyzed variable. Rio de Janeiro, RJ, 2014. Source: created by the author.

lesion. Using the Payne-Martin Classification System, one study recommends that category I lesions - those without tissue loss - should be cleansed with saline solution and the skin flap replaced over the wound. The skin flap itself, when viable, has proved to be the best possible way to close skin tears. A primary silicone-based dressing is also recommended (left in place no longer than 7 days), with an arrow indicating the correct direction so that other 
professionals - who might have to conduct evaluations can remove the skin flap without extracting it partially or completely and thus compromise its ability to cover the lesion. The study advocates that after the dressing is in place, the care plan must be re-elaborated, the next review date established and data recorded correctly so as to prevent complications. Category II and III lesions present similar care procedures. For category II, it is recommended that the skin flap be replaced over the wound (by rolling) with the help of a cotton swab, due to complications caused by tissue loss. Category III lesions require that a secondary dressing be applied, made out of absorbent foam, in order to better control the exudate, and which must be changed within 5 days. ${ }^{(1,9)}$

One case study demonstrated success in preventing skin tears in an elderly patient who underwent surgery in which an elliptic incision was performed. Since this patient presented skin frailty, ${ }^{(13)}$ a porous and hypoallergenic adhesive tape made of polyester was recommended in order to prevent new trauma, reduce the risk of bleeding, and prevent infection, all of which can delay wound healing.(6) In order to avoid trauma while removing the adhesive tape, a specific remover was used. The authors make clear that nurses can also use vegetable oil for this purpose. ${ }^{(14)}$ Although they were concerned with conducting removal in the least traumatic manner, this proposal diverges from that of other authors who discourage the use of adhesive dressings due to the risk of damage (albeit small) to the skin flap, the lesion itself, and the periwound, during removal. ${ }^{(5-7,9-10)}$

Octylcyanoacrylate-based products demonstrated the greatest potential for treating skin tears. ${ }^{(5,8,10)}$ It is a liquid adhesive manufactured by different laboratories, which does not damage skin when removed. Octylcyanoacrylate-based adhesives have proven to promote a homeostatic effect, effective protection against bacterial penetration, faster epitelization, and pain reduction. They also maintain the humidity at an ideal level(8) for healing. One study ${ }^{(5)}$ demonstrated that 18 out of 20 patients with category II and III skin tears (according to the Payne-Martin system) who were treated with this type of dressing needed only one application (which was left in place for one week). This indicates the possibility for reducing costs, optimizing nurses' work time, and enabling patients to maintain their daily activities such as taking a bath normally. As a side effect, this study verified that only one patient presented moderate pain. It is contraindicated for lesions which cut through the dermal layers and are penetrating, presenting uncontrolled hemorrhage and active areas of infection, and are located in very hairy regions. The dressing is applied by cleansing the region with saline solution, "milking" the borders of the lesion in order to remove as much sanguineous exudate as possible with the help of a sterile gauze, approximating the skin flap to the borders (if such exists), applying the product approximately 1 to $2 \mathrm{~cm}$ beyond the margins of the skin tear, and finally, allowing the area to dry for 15 to 30 seconds. No secondary dressing is necessary and it must be reapplied at the end of seven days.

As long as the indications and contraindications of each product are respected, other primary or secondary dressings can be applied. Non- or low-adherent dressings, such as hydrocolloid, foam, hydrogel, petrolatum impregnated gauze, hydrofiber or calcium alginate (the latter two for very exudative lesions) can be used by nurses after cleansing the skin tear by first irrigating the wound preferentially with a warm physiological solution, followed by drying naturally or with a sterile gauze. ${ }^{(8-10)}$ If skin tears present signs of inflammation, the dressing must be left on for less time than those without a sustained infection/inflammation. The last consensus ${ }^{(8)}$ on the topic also defends that necrotic or devitalized tissues be removed and, depending on the institution, tetanus vaccination may be administered as part of the therapeutic treatment plan.

It is reiterated that, whenever possible, the nurse use the skin flap itself for covering up the skin tear. ${ }^{(6,10)}$ When this is not possible, the products mentioned above are the alternatives recommended by scientific evidence for treating skin tears, due to their non or low adherence.

Pain can compromise quality of life and make healing more difficult. It can be managed by using specific coverings such as octylcyanoacrylate-based dressings or by taking analgesics. ${ }^{(9)}$ Nevertheless, it is necessary to keep in mind that some drugs can act as a risk factor for skin tears. ${ }^{(14)}$

The majority of studies used the Payne-Martin system for classifying skin tears. Created in $2007^{(15)}$, revised in $2010^{(16)}$ and translated into Portuguese in $2010^{(17)}$, it is the most up-to-date classification system available, although it has not been broadly used. ${ }^{(9)}$ Use of the Skin Tear Classification System (STAR) in conjunction with others such as the Karnofsky and Braden scales has demonstrated great potential, considering its utility for evaluating the level of dependence of hospitalized elderly patients and their risk for pressure ulcers. ${ }^{(3,18-19)}$

\section{On skin tear prevention strategies carried out by nurses}

An integral, detailed, routine examination, which duly registers the patient's skin condition, can be of great help for preventing and managing skin tears. Such an examination will allow for differentiating skin tears from other 
lesions and help nurses to track, eliminate or minimize risk factors. ${ }^{(6,8,20-21)}$ One study showed that in some cases skin tears could have been caused by small trauma even before the patient's admission into the health institution, which indicates the need for nurses to conduct educational activities with patients, caretakers and family members about the risks of an unfavorable care environment.(1)

Although skin tears cannot always be prevented, nurses must be vigilant and apply the correct techniques for manipulating, changing positions and transferring the patient from one bed/gurney to another in order to avoid friction, shearing and contusions. A balanced nutritional program can also favor greater skin resistance. Thus, one of the most important recommendations found in these studies is to aim for a multidisciplinary approach for skin tear prevention and management activities. ${ }^{(6,8)}$ The care plan for the patient with skin tears should be formulated collaboratively, so that nurses, other members of the team, caretakers, family members and patients themselves can participate and contribute to defining the best path towards therapeutic success.

A safe environment is a critical component of a prevention plan for this type of wound. ${ }^{(9)}$ One quantitative study states that there must be constant concern regarding the design of the hospital bed, which can offer risks to skin integrity. The ideal bed design can reduce the risk for skin tears and pressure ulcers, even though its development is quite complex and is still in progress. ${ }^{(4)}$ Even the choice of soap needs to be discussed among nursing professionals and others involved in the care process. Alkaline, antibacterial and highly perfumed soaps must be avoided, for they reduce skin lubrication and alter the profile of its flora. Instead, one can use emollient, $\mathrm{pH}$ neutral and/or Aloe vera soap. ${ }^{(9-10)}$ Attention must also be given to the weather or environmental conditions, which favor the occurrence of skin tears, such as high temperatures in summer. ${ }^{(21)}$

According to this review, there is a lack of studies that investigate the prevalence, incidence and economic impact of skin tears in Brazil and in the world. ${ }^{(8)}$ This review presented limitations, such as considering only articles available in full text, but it indicates directions so that general-practice nurses and, in particular, specialized enterostomal therapy nurses, can identify the most common risk factors, understand the most current protocols and classification systems, and be familiar with the resources available that can produce the best results, in order to implement care practices in consonance with the latest scientific evidence.(22)

It is up to health institutions to supply the necessary organizational support for the best practices for skin tear management.

\section{CONCLUSIONS}

Scientific articles in the field of nursing over the last ten years regarding skin tears indicate that although the best dressings are those which use the skin flap itself or are octylcyanoacrylate or silicone-based, skin tear management by nurses can vary according to the patient's clinical status, institutional resources, and the body of knowledge of professionals managing the patient's care, among other issues.

Basic nursing care objectives for this type of patient are to avoid infections, trauma of any intensity, pain and bleeding, as well as to promote a therapeutic environment which is favorable to the fastest possible healing.

Despite the limitations of this review, especially with regard to the low number of studies found, we indicate scientific evidence that can be useful for the nursing care of patients with skin tears. Further research can be developed to confirm or refute the results of this study, analyzing skin tears in Brazil through multiple theoretical and methodological prisms.

\section{REFERENCES}

1. Lopez V, Dunk AM, Parke J, Larkin D, Trudinger M, Stuart M. Skin tear prevention and management among patients in the acute aged care and rehabilitation units in the Australian Capital Territory: a best practice implementation project. Int J Evid Based Healthc. 2011;9(4):429-34.

2. Maida V, Ennis M, Corban J. Wound outcomes in patients with advanced illness. Int Wound J. 2012;9(6):683-92.

3. Amaral AFS, Pulido KCS, Santos VLCG. Prevalence of skin tears among hospitalized patients with cancer. Rev Esc Enferm USP. 2012;46(Esp):44-50.

4. Kotowski SE, Davis KG, Wiggermann N, Williamson R. Quantification of patient migration in bed: catalyst to improve hospital bed design to reduce shear and friction forces and nurse's injuries. Hum Factors. 2013;55(1):36-47.

5. Milne CT, Corbett LQ. A new option in the treatment of skin tears for the institutionalized resident: formulated 2 octylcyanoacrylate topical bandage. Geratr Nurs. 2005;26(5):321-5.

6. Ousey K. Identifying, managing and treating skin tears. Br J Community Nurs. 2009;23(9):18-22.

7. Benbow M. Skin tears. Br J Community Nurs. 2009;23(1):14-8.

8. LeBlanc K, Baranoski S. Skin tears: state of the science: consensus statements for the prevention, prediction, assessment, and treatment of skin tears. Adv Skin Wound Care. 2011;24(9):2-15.

9. Holmes RF, Davidson MW, Thompson BJ, Kelechi TJ. Skin tears: care and management of the older adult at home. Home Healthc Nurse. 2013;31(2):90-101.

10. Xu XBS, Lau K, Taira BR, Singer AJ. The current management of skin tears. Am J Emerg Med. 2009;27(6):729-33.

11. Mendes KDS, Silveira RCCP, Galvão CM. Revisão integrativa: método de pesquisa para a incorporação de evidências na saúde e na enfermagem. Texto Contexto Enferm. 2008;17(4):758-64.

12. Galvão CM, Sawada NO, Mendes IAC. A busca das melhores evidências. Rev EsC Enferm USP. 2003;37(4):43-50.

13. Foster RS, Chan J. The Fixomull skin support method for wound closure in patients with fragile skin. Aust J Dermatol. 2011;52(3):209-11. 
14. Cuzzell J. Wound assessment and evaluation: skin tear protocol. Dermatol Nurs. 2003;14(6):405

15. Caville K, Lewin G, Newall N, Haslehurst P, Michael R, Santamaria N, et al. STAR: a consensus for skin tear classification. Prim Intention. 2007;15(1):8-25.

16. Curtin University of Technology. Silver Chain Nursing Association. School of Nursing Midwifery. STAR skin tear classification system guidelines [Internet]. Curtin, Australia; 2010 [citado 2013 April 23]. Disponível em: http://www.silverchain.org.au/assets/GROUP/research/STAR-Skin-Tear-tool-04022010.pdf

17. Strazzieri-Pulido KC, Santos VLCG. Cultural adaptation and validation of STAR Skin Tear Cassification System for Brazilians [abstract]. Wound Ostomy Continence Nurs J. 2011;38(3S):S92.
18. Urbanetto JS, Roberta M, Carvalho SM, Creutzberg M, Oliveira KF, Magnago TBS. Degree of dependence of hospitalized elderly according to the patients' classification system. Rev Bras Enferm. 2012;65(6):950-4.

19. Bajwa AA, Arasi L, Canabal JM, Kramer DJ. Automated prone positioning and axial rotation in critically ill, nontrauma patients with acute respiratory distress syndrome (ARDS). J Intensive Care Med. 2010;25(2):121-5.

20. Kazandjiean DG, Okulicz JF. Skin tears? Am J Med. 2006;119(8):657-9

21. Kennedy P, Kerse N. Pretibial skin tears in older adults: a 2-year epidemiological study. J Am Geriatr Soc. 2011:59(8):1547-8.

22. Santos Él, Gomes AMT, Barreto EAS, Ramos RS. Evidências científicas sobre fatores de risco e sistemas de classificação das skin tears. Rev Enferm Atual In Derme. 2013:64:16-21.

\section{Author's address:}

Érick Igor dos Santos

Rua Recife, s/n, Jardim Bela Vista

28895-532, Rio das Ostras, RJ

E-mail: eigoruff@gmail.com
Received: 20.02.2014

Approved: 08.05.2014 